\title{
Role of the Ryanodine Receptor of Skeletal Muscle in Excitation-Contraction Coupling
}

\author{
MICHAEL FILL, ${ }^{a}$ JIANJIE MA, ${ }^{a}$ C. MICHAEL KNUDSON,${ }^{b}$ \\ TOSHIAKI IMAGAWA, ${ }^{b}$ KEVIN P. CAMPBELL, ${ }^{b}$ \\ AND ROBERTO CORONADO ${ }^{a}$ \\ ${ }^{a}$ Department of Physiology and Molecular Biophysics \\ Baylor College of Medicine \\ Houston, Texas 77030 \\ ${ }^{b}$ Department of Physiology and Biophysics \\ The University of Iowa School of Medicine \\ Iowa City, Iowa 52242
}

In skeletal muscle, contraction is initiated by a depolarization of the transverse tubular membrane (t-tubule), which in turn signals the release of $\mathrm{Ca}$ from the sarcoplasmic reticulum (SR). A key protein involved in this process is the ryanodine receptor, an SR membrane protein of MW 450,000 that binds the alkaloid ryanodine with nanomolar affinity and is present exclusively at the junction between t-tubule and SR membranes. ${ }^{1-4}$ The ryanodine receptor plays a dual role: Functionally, it is the putative Ca-release channel of the SR, ${ }^{4}$ and structurally, it is the major protein responsible for forming "bridges" or "feet" that anatomically connect t-tubule and SR. ${ }^{2,5}$ Here we demonstrate that the ryanodine receptor is steeply gated by both voltage and protons, and for the first time in vitro, we measured nonlinear capacitance (charge movement) that may be involved in the gating of this channel protein.

We recently identified the $450,000-\mathrm{Da}$ ryanodine receptor-feet protein (FIG. 1A) as the Ca-release channel of native SR. ${ }^{4,9,10}$ This was achieved using the planar bilayer recording technique and by comparing ligand-dependent gating, ionic selectivity, and pharmacology of purified ryanodine receptors to that of native Ca-release channels. ${ }^{11,22}$ Voltage dependence was a gating property notoriously absent in our study and in studies by others that followed. ${ }^{12,13}$ Its inconspicuousness in our earlier work is related to the effect of protons. At $\mathrm{pH} 7.4$ (FIG. 1B) the channel dwells in a fast gating mode $(p=0.38)$. A drop to $\mathrm{pH} 7.2$ drives the channel into an almost closed condition ( $p$ $=0.08)$ and at $\mathrm{pH} 7.0$ the channel never opens $(p<0.01)$. Reversibility is shown in the last record of FIGURE 1 where alkalinization from $\mathrm{pH} 7.0$ to $\mathrm{pH} 7.6$ reopens the channel, resulting in a higher level of activity $(p=0.72)$ than seen at $\mathrm{pH} 7.4$. Over this narrow range of $\mathrm{pH}$, slope conductance is not affected (FIG. 2C, inset), and the kinetics remain fast, with a mean open event duration of approximately $100 \mu \mathrm{sec}$. Thus for all practical purposes, a change of 0.6 unit in solution $\mathrm{pH}$ from 7.6 to 7.0 units is sufficient to make the channel switch from an almost all-open to an almost all-closed conformation. The fitted Hill coefficient for data in FIGURE 1 was $n=6.8$ and the apparent $\mathrm{p} K_{\mathrm{a}}$ was 7.5. FIGURE 2 describes the ensuing changes in voltage 


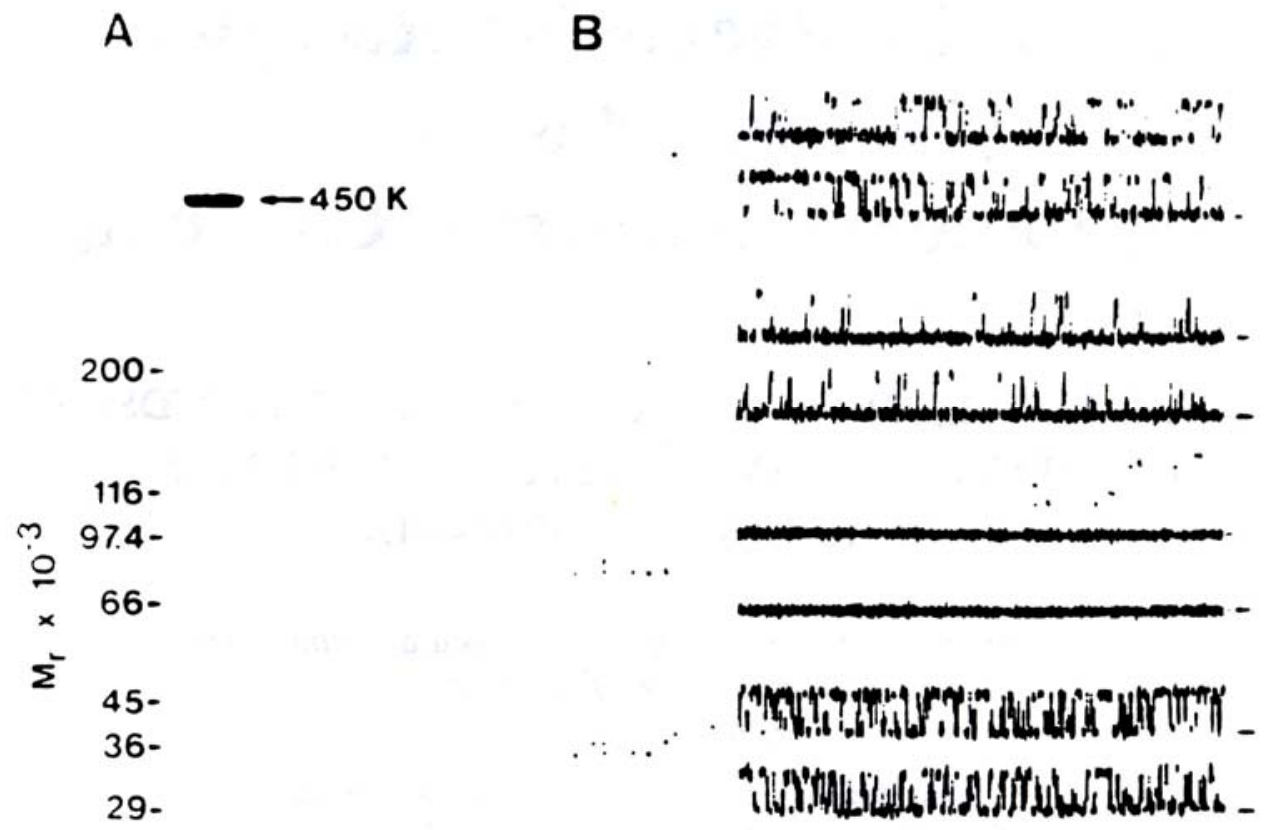

FIGURE 1. Ryanodine receptor polypeptide composition and $\mathrm{pH}$ dependence of purified receptor channels. (A) SDS-PAGE analysis of $3 \mu \mathrm{g}$ of purified ryanodine receptor on 3-12\% gradient gel and stained with Coomassie blue. The 450,000-Da receptor, indicated by the arrow (450K), migrated as a single band. Standards are indicated at the left. Purity of the 450,000-Da protein determined by gel scans was greater than $95 \%$. Scatchard analysis of $\left[{ }^{3} \mathrm{H}\right]$ ryanodine binding to the purified receptor (detailed in Smith et al. ${ }^{10}$ ) yielded a straight line with an apparent $\mathrm{B}_{\max }$. and $K_{\mathrm{d}}$ of 490 pmoles/mg and $7.0 \mathrm{nM}$, respectively. (B) Single-channel activity mediated by the purified receptor in solutions of different $\mathrm{pH}$. All records from the same experiment, HP $+60 \mathrm{mV}$ (380 pS open-channel conductance), 3-kHz cutoff frequency. Baseline current is indicated next to each record. Solutions in both chambers were $0.25 \mathrm{M} \mathrm{KCl}, 0.5 \mathrm{mM}$ EGTA (pCa 7). $25 \mathrm{mM}$ MOPS (3-[n-morpholino]propanesulfonic add) $\mathrm{pH} 7.4 \mathrm{pH}$ (indicated next to each record) was adjusted with calibrated aliquots of MOPS (free acid) or KOH. To increase frequency response, $\mathrm{K}$ ions (instead of $\mathrm{Ca}$ or $\mathrm{Ba}$ ) were used as current carriers. At low $\mathrm{Ca}$ ( $\mathrm{pCa}$ $>6$ ), $\mathrm{K}$ conductance is 6-10-fold larger than Ca conductance (detailed in Smith et al. ${ }^{10}$ ).

Ryanodine receptor was purified from isolated adult rabbit skeletal muscle triads by immunoaffinity chromatograpby (as in Imagawa et al. ${ }^{4}$ with modifications introduced in Smith et al. $\left.{ }^{10}\right)$. Isolated triads were solubilized in $1 \%$ CHAPS in $0.5 \mathrm{M} \mathrm{NCl}$ and buffer A $(0.5 \mathrm{M}$ sucrose, $0.75 \mathrm{~m} M$ benzamidine, $0.1 \mathrm{mM}$ PMSF, and $50 \mathrm{mM}$ Tris- $\mathrm{HCl}$ at $\mathrm{pH} \mathrm{7.4)} \mathrm{at} \mathrm{the} \mathrm{protein}$ concentration $1 \mathrm{mg} / \mathrm{ml}$ in the presence of several protease inhibitors. Solubilized triads were applied to a MAb-XA7-Sepharose column $(20 \mathrm{ml})$ and recycled overnight. Receptor was eluted in $0.3 \%$ CHAPS, $0.15 \%$ asolecithin, and $0.5 \mathrm{M} \mathrm{KSCN}$ in buffer A. KSCN was exchanged for KC1 using a Pharmada PD-10 column. Planar bilayers were cast from $20 \mathrm{mg} / \mathrm{ml}$ brain phospholipids in decane (PE/PS $=1 / 1 \mathrm{wt} / \mathrm{wt}$ ). The two chambers in contact with the bilayer were denned as cis (side of receptor addition, connected to head-stage amplifier) and trans (protein-free side, connected to ground potential). Solutions in cis and trans chambers were the same, $250 \mathrm{mM} \mathrm{KCl,} 1 \mathrm{mM}$ EGTA (pCa 7), $25 \mathrm{mM}$ MOPS pH 7.0, 7.2, 7.4. or 7.6. For capadtance measurements we used $50 \mathrm{mM} \mathrm{NaCl}$ and $10 \mathrm{mM}$ HEPES-TRIS, pH 7.2. Receptor concentration in solutions was $0.5-1 \mu \mathrm{g} / \mathrm{ml}$ for single-channel measurements and $80-100 \mu \mathrm{g} /$ $\mathrm{ml}$ from capacitance measurements. An equal amount of receptor buffer $(0.3 \%$ CHAPS, $0.15 \%$ asoledthin, $0.5 \mathrm{M} \mathrm{KCl} ; 50 \mathrm{mM}$ Tris $\mathrm{pH}$ 7.2) was always present in the trans chamber. At the concentrations used, CHAPS detergent (3-[(3-cholamidopropyl)dimethylammonio]-1-propanesulfonate) had no effect on conductance or mechanical stability. Head-stage amplifier was a List EPC7 (List-Electronic, DA-Eberstadt, West-Germany) and pulse protocols were constructed using Basic-Fastlab software (Indec System, Sunnyvale, CA, USA). Current records were filtered at 3-10-kHz corner frequency on an eight-pole Bessel (Frequency Devices, Haverhill, MA, USA) and digitized at 14-30 $\mu \mathrm{sec} /$ point. 


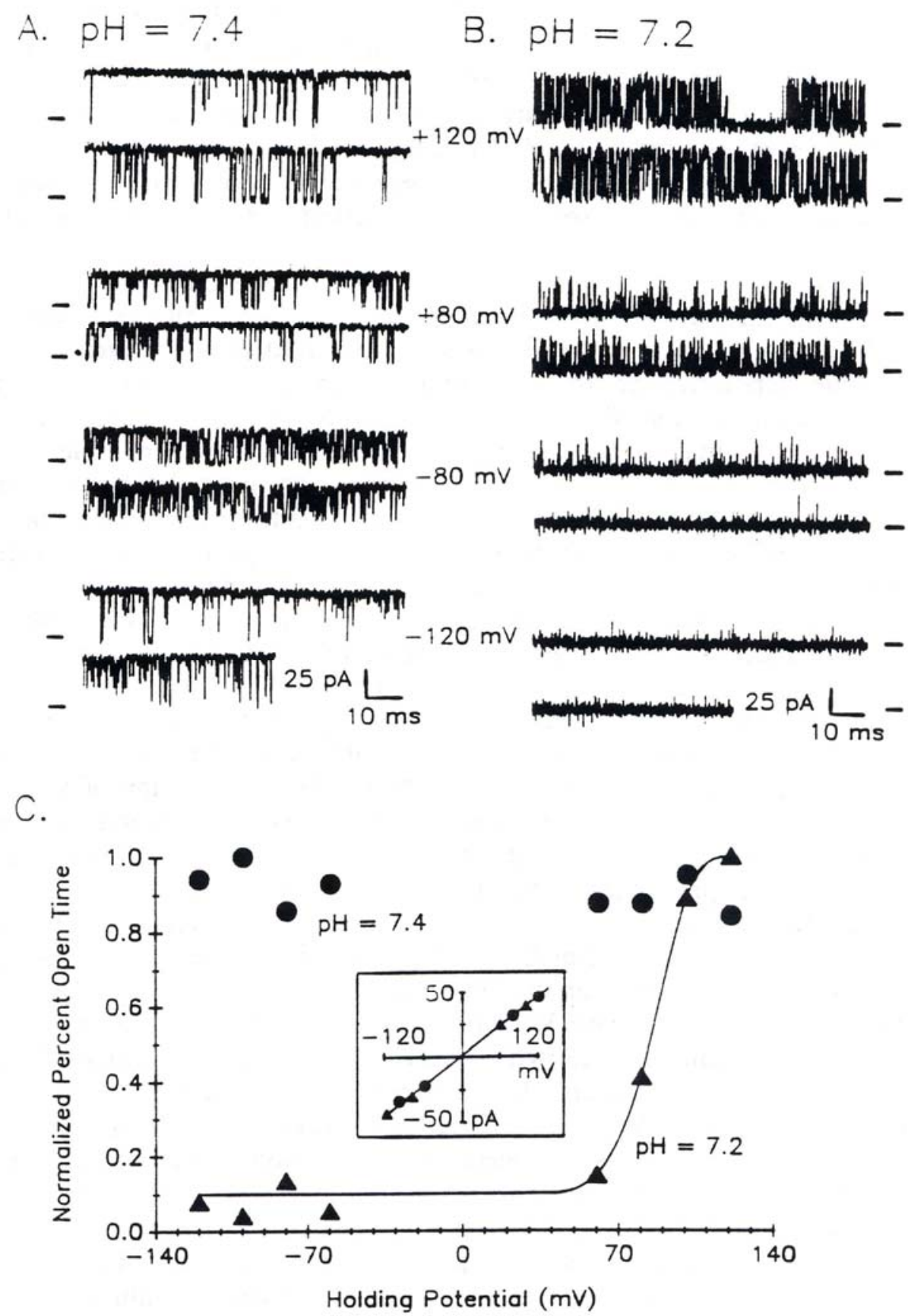

FIGURE 2. Voltage-dependence of ryanodine receptor channel. (A,B) Channel activity in cis solution $\mathrm{pH} 7.4$ and 7.2 at the indicated holding potentials. Openings at every voltage are shown as deflecting the trace upward. Baseline is given for each trace. (C) The fraction of time spent open during a representative 10 -sec interval ( $p$, open probability) is plotted against holding potential at $\mathrm{pH} 7.2$ (triangles) and $\mathrm{pH} 7.4$ (circles), $p$ at $\mathrm{HP}+100 \mathrm{mV}$ was given a value of unity at both pHs. Actual values are $p=0.82(\mathrm{pH} \mathrm{7.4)}$ and $p=0.41(\mathrm{pH} \mathrm{7.2)}$. The current voltage curve (inset) at each $\mathrm{pH}$ was adequately fitted by the same line with a slope of $380 \mathrm{pS}$. 
dependence. At pH 7.4 (FIG. 2A), the open probability remains fairly constant over the complete range of test potential, $+120 \mathrm{mV}$ to $-120 \mathrm{mV}$. In this experiment open probability averaged 0.87 (FIG. 2C, circles). At pH 7.2 (FIG. 2B), a similar level of activity was present at positive potentials, and it dropped to 0.02 and less at potentials below $+50 \mathrm{mV}$ (FIG. 2C, triangles). Transition from open to closed was steep, with a midpoint at $+85.7 \mathrm{mV}(9.3 \mathrm{mV}$ standard deviation, $n=8)$ and an e-fold increase in open probability every $3.5 \mathrm{mV}$. At pH 7.0 no openings were observed at any test potential. Thus, the receptor channel is steeply dependent on both membrane potential and $\mathrm{pH}$ with the switching from closed to open occurring over an unusually narrow range.

A demonstration of voltage dependence prompted us to search for charge movement associated with this protein. In skeletal muscle, nonlinear charge movements are argued to be a manifestation of some molecular event that is involved in transduction of t-tubule depolarization to SR calcium release. Experimentally, charge movement was looked for as a small voltage-dependent component of the total membrane capacitance. To ensure a large density of receptors in the planar membrane, we used 100-200 times more protein $(80 \mu \mathrm{g} / \mathrm{ml})$ than used in single-channel experiments. To avoid trivial artifacts related to adding receptor to only one chamber, we added protein-free receptor buffer (see legend FIG. 1) to the opposite chamber. Hence, the only asymmetry in the system was the protein itself. We measured the voltagedependent component of membrane capacitance, $\mathrm{C}(\mathrm{V})$, as a function of holding potential, V. Capacitance was determined in the range of $-150 \mathrm{mV}$ to $+150 \mathrm{mV}$ by integrating of the "on" or "off" charging current in response to a constant test pulse. The test pulse was applied midway during a long holding pulse. In order to compare the shape of the voltage-dependent component, we subtracted the capacitance at $\mathrm{V}$ $=0 \mathrm{mV}$ from each curve and plotted $\mathrm{C}(\mathrm{V})-\mathrm{C}(\mathrm{V}=\varnothing)$ as a function of $\mathrm{V}^{2}$ (FIG. $3)$. Bare bilayers and bilayers with protein-free buffer displayed a characteristic minimum at $\mathrm{V}=0 \mathrm{mV}$ and a quadratic increase in $\mathrm{C}(\mathrm{V})$ as a function of $\mathrm{V}$, symmetric with respect to zero. This phenomenon has been well described and is due to electrostriction. ${ }^{14,15}$ Capacitance of bare bilayers was typically $12 \%$ higher at $+150 \mathrm{mV}$ (or $-150 \mathrm{mV}$ ) than at $0 \mathrm{mV}$. A plot of $\mathrm{C}(\mathrm{V})$ versus $\mathrm{V}^{2}$ (FIG. 3, circles) shows that in the absence of receptor each arm of the curve, the one at positive and the one at negative potentials, varies linearly with $\mathrm{V}^{2}$ with a slope of approximately $4.9 \mathrm{pF} / \mathrm{V}^{2}$. Receptor protein (FIG. 3, triangles) had two effects on this relationship. It significantly increased the steepness at positive potentials, and it decreased the steepness at negative potentials. The effects are complex with no less than three slopes clearly different from the slope expected on the basis of electrostriction alone. One component at negative potentials is weakly voltage dependent; a second component around $0 \mathrm{mV}$ is steeply voltage dependent, and a third component at large positive potentials tends to saturate with a limiting slope of about $20 \mathrm{pF} / \mathrm{V}^{2}$, six times larger than without receptor. Thus clearly, the ryanodine receptor in vitro mediates nonlinear charge movement of several kinds.

Although we could not specify components responsible for gating, the bulk of the charge correlated well with open-channel probabilities. FIGURE 4A shows receptor charge movement (protein minus protein-free capacitance) as a function of holding voltage. More charge is moved at progressively positive potentials with the largest change occurring between $-60 \mathrm{mV}$ and $+60 \mathrm{mV}$. Under similar conditions, records of single channels are shown in FIGURE 4B. Activation occurs at positive potentials with few openings below $+60 \mathrm{mV}$. Thus the two processes have voltage dependencies that increase in the same direction. This is plotted in FIGURE 4C where charge movement during either the "on" transient (squares) or "off" transient (circles) was found to be superimposable with open-channel probabilities (diamonds). The latter 
measured independently from single-channel records obtained at a low concentration of receptor. The equivalence of charge moved during the "on" and "off" of the test pulse is given in the inset of FIGURE 4. One followed the other in the protein-free control (lower curves) and in the presence of receptor (upper curves).

Four hallmarks of $\mathrm{Ca}$ release studied in skinned fibers and SR vesicles, ${ }^{16-25}$ namely, activation of release by micromolar $\mathrm{Ca}$ and millimolar adenine nucleotide, and inhibition by micromolar ruthenium red and millimolar $\mathrm{Mg}$, can be traced to the channel formed by the 450,000 -Da ryanodine receptor. ${ }^{10}$ The purified polypeptide alone contains the binding site for ryanodine and the regulatory sites for $\mathrm{Ca}, \mathrm{ATP}$, and ruthenium

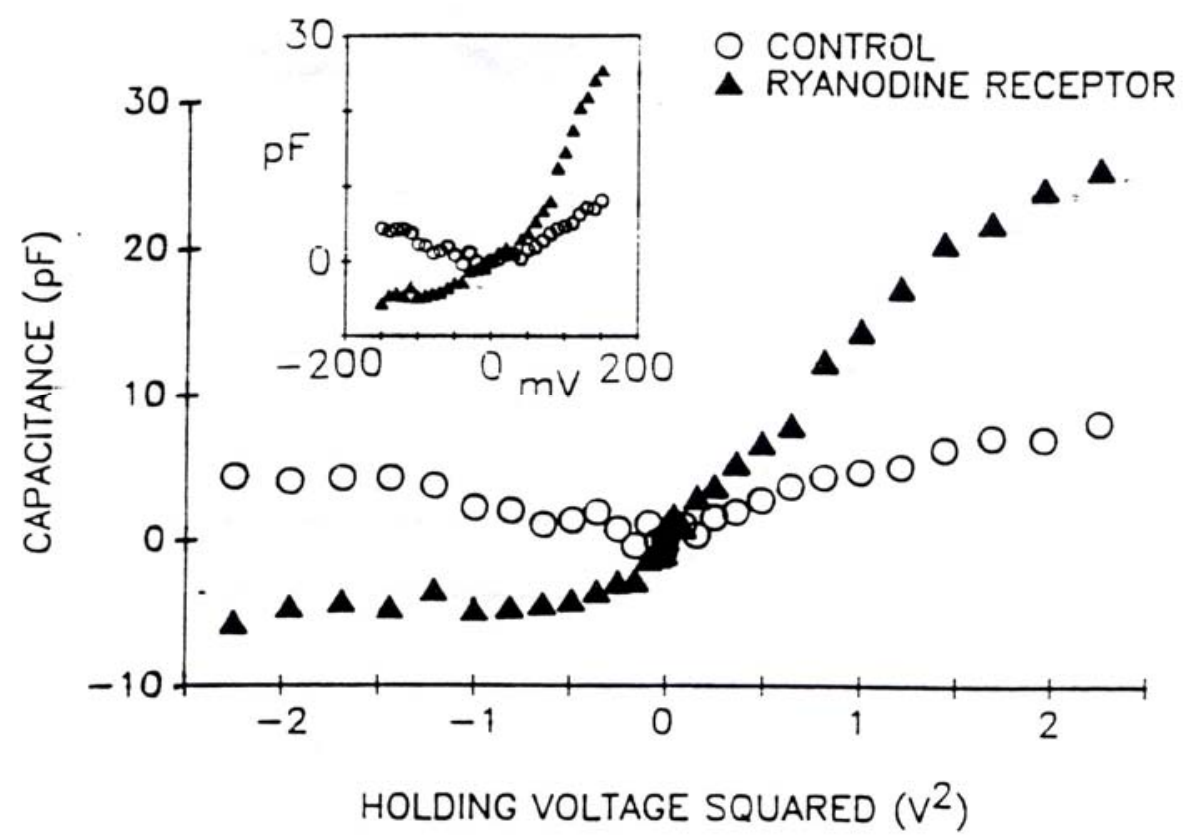

FIGURE 3. Voltage-dependent capacitance mediated by ryanodine receptor. Capacitance as a function of voltage $\mathrm{C}(\mathrm{V})$, was measured using a two-pulse protocol. A square voltage pulse of 10 -mscc duration and constant $+10 \mathrm{mV}$ amplitude (test pulse) was added to square voltage pulse of $200-\mathrm{mscc}$ duration and variable amplitude (holding voltage pulse). Test pulse was applied $100 \mathrm{msec}$ into the holding pulse. Holding voltage was varied between $-150 \mathrm{mV}$ to $+150 \mathrm{mV}$. Capacitance was measured by integrating the first $8 \mathrm{msec}$ of the "on" transient of the test pulse at each holding voltage. Curves are the average of four separate experiments. Circles correspond to bilayers with receptor protein and receptor buffer on the cis and trans sides, respectively. Capacitance at $0 \mathrm{mV}$ holding voltage was subtracted from each curve (control $\mathrm{C}(\mathrm{V}=0)=314 \mathrm{pF}$; ryanodine receptor $\mathrm{C}(\mathrm{V}=0)=347 \mathrm{pF}$. $\mathrm{C}(\mathrm{V})-\mathrm{C}(\mathrm{V}=0)$ is plotted against holding voltage, $\mathrm{mV}$ (inset) or $\mathrm{V}^{2}$ (center).

red. ${ }^{4}$ The identified receptor channel is novel in several respects. It has a large conductance for $\mathrm{K}$ and $\mathrm{Ca}$ ions and a fast kinetics composed of open times in the range of $60-100 \mu$ sec. $^{10}$ These properties are expected of a channel that mediates SR Ca release. The ryanodine receptor in vivo forms part of a large oligomeric structure that spans the $100-\AA$ gap between t-tubules and SR membranes., ${ }^{2,12,13}$ Recent evidence suggests that the attachment to the t-membrane may contain the dihydropyridine (DHP) receptor. ${ }^{26}$ The DHP receptor has been identified as the t-tubule voltage sensor of excitation-contraction coupling. ${ }^{8}$ Thus, our observation of nonlinear capacitance may lead to the possibility that the ryanodine receptor protein may sense and convey 

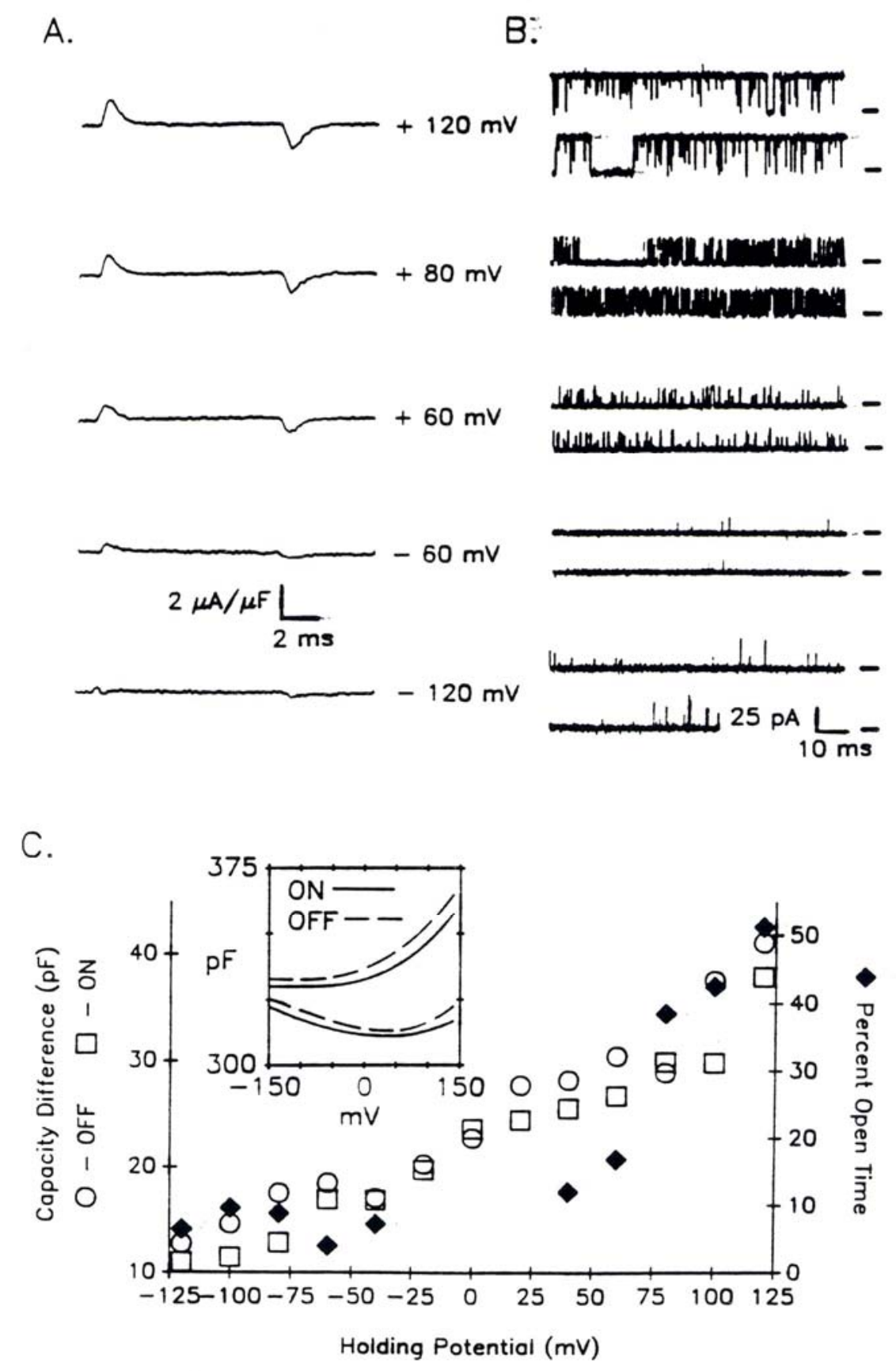

FIGURE 4. Correlation charge movement and channel opening in the ryanodine receptor. (A) Charge movement mediated by the receptor protein obtained by subtracting pairs of test pulses (protein minus protein free) at each indicated holding potential. (B) Single-channel activity at the corresponding holding voltages measured in a separate experiment. Channel opening is always shown as upward deflections from the baseline which is indicated for each record. (C) Capacitance difference after subtraction of protein minus protein-free bilayers (open symbols) and openchannel probability (filled diamonds) are plotted against holding voltage. Inset shows C(V) versus $\mathrm{V}$ separately in protein-free (lower curves in inset) and protein-containing (upper curves in inset) bilayers. The "on” and "off” transients have the same voltage dependence. 
t-tubule voltage changes to the SR. Further experiments, however, emphasizing the pharmacology and specificity of the nonlinear capacitance are required to assess its significance in vivo.

\section{REFERENCES}

1. Pessah, I. N., A. O. Francini, D. J. Scales, A. L. Waterhouse \& J. E. Casida. 1986. Calcium ryanodine receptor complex solubilization and partial characterization from skeletal muscle functional sarcoplasmic reticulum vesicles. J. Biol. Chem. 261: 8643-8648.

2. InUI, M., A. SATTO \& S. FleischeR. 1987. Purification of the ryanodine receptor and identity with feet structures of functional terminal cisternae of sarcoplasmic reticulum from fast skeletal muscle. J. Biol. Chem. 262: 1740-1747.

3. Campbell, K. P., C. M. Knudson, T. Imagawa, A. T. Leung, J. L. SutKo, S. D. KAHL, C. R. RAAB \& L. MADSON. 1987. Identification and characterization of the high affinity $\left[{ }^{3} \mathrm{H}\right]$ ryanodine receptor of the junctional sarcoplasmic reticulum $\mathrm{Ca}^{2+}$ release channel. J. Biol. Chem. 262: 6460-6463.

4. Imagawa, T., J. S. Smith, R. Coronado \& K. P. CAmpbell. 1987. Purified ryanodine receptor from skeletal muscle sarcoplasmic reticulum is the $\mathrm{Ca}^{2+}$ permeable pore of the calcium release channel. J. Biol. Chem. 262: 16636-16643.

5. Ferguson, D. G., H. W. SChWARTZ \& C. Franzini-ArmStrong. 1984. Subunit structure of junctional feet in triads of skeletal muscle: A freeze-drying, rotatory-shadowing study. J. Cell Biol. 99: 1735-1742.

6. Melzer, W., M. F. Schneider, B. J. Simon \&. G. Szucs. 1986. Intramembrane charge movement and calcium release in frog skeletal muscle. J. Physiol. 373: 481-511.

7. Berwe, D., G. Gottschalk \& H. Ch. Luttgau. 1987. Effects of the calcium antagonist gallopamil (D600) upon excitation-contraction coupling in toe muscle fibers of the frog. J. Physiol. 385: 693-707.

8. Rios. E. \& G. BRUM. 1987. Involvement of dihydropyridine receptors in excitation-contraction coupling in skeletal muscle. Nature 325: 717-720.

9. Smith, J. S., T. Imagawa, K. P. CAmpbell \& R. CoRonado. 1988. Permeability and gating properties of the purified ryanodine receptor-calcium release channel from skeletal muscle sarcoplasmic reticulum. Biophys. J. 53: 422a.

10. Smith, J. S., T. Imagawa, J. Ma, M. Fill, P. K. Campbell \& R. Coronado. 1988. Purified ryanodine receptor from rabbit skeletal muscle is the calcium release channel of sarcoplasmic reticulum. J. Gen. Physiol. 92(1): 1-27.

11. Smith, J. S., R. Coronado \& G. Meissner. 1986. Single-channel measurements of the calcium release channel from skeletal muscle sarcoplasmic reticulum. Activation by calcium ATP and modulation by magnesium. J. Gen. Physiol. 88: 573-588.

12. Lai, F. A., H. P. ERIKSON, E. Rousseau \& G. MEISSNER. 1988. Purification and reconstitution of the calcium release channel from skeletal muscle. Nature 331: 315-319.

13. Hymel, L., M. InUI, S. Fleischer \& H. G. SChIndLER. 1988. Purified ryanodine receptor of skeletal muscle sarcoplasmic reticulum forms $\mathrm{Ca}^{2+}$-activated oligomeric $\mathrm{Ca}^{2+}$ channels in planar bilayers. Proc. Natl. Acad. Sci. USA, in press.

14. AlvareZ, O. \& R. LATORRE. 1978. Voltage-dependent capacitance in lipid bilayers made from monolayers. Biophys. J. 21: 1-17.

15. WHITE, S. 1980. How electric fields modify alkane solubility in lipid bilayers. Science 207: 1075-1077.

16. Meissner, G., E. Darling \& J. Eveleth. 1986. Kinetics of rapid $\mathrm{Ca}^{2+}$ release by sarcoplasmic reticulum effects of $\mathrm{Ca}^{2+}, \mathrm{Mg}^{2+}$, and adenine nucleotides. Biochemistry 25:236-243.

17. OgaWA, Y. \& S. EBASHI. 1983. J. Biochem. Tokyo 93: 1271-1285.

18. ENDO, M. \& O. KITAZAWA. 1976. Proc. Japan Acad. 52: 599.

19. Moril, H. \& Y. TONOMURA. 1983. The gating behavior of a channel for $\mathrm{Ca}^{2+}$ induced release in fragmented sarcoplasmic reticulum. J. Biochem. Tokyo 93: 1271-1285. 
20. NAGASAKI, K. \& M. KASAI. 1983. Fast release of calcium from sarcoplasmic reticulum vesicles monitored by chlortetracycline fluorescence. J. Biochem. Tokyo 94: 1101-1109.

21. VolPe, P., G. SAlvati \& A. ChU. 1986. Calcium-gated calcium channels in sarcoplasmic reticulum of rabbit skinned skeletal muscle fibers. J. Gen. Physiol. 87: 289-303.

22. SMITH, J. S., R. CORONADO \& G. MEISSNER. 1985. Sarcoplasmic reticulum contains adenine nucleotide-activated calcium channels. Nature 361: 446-449.

23. Fabiato, A. 1985. Time and calcium dependence of activation and inactivation of calciuminduced release of calcium from the sarcoplasmic reticulum of a skinned canine cardiac purkinje cell. J. Gen. Physiol. 85: 247-289.

24. STEPHENSON, E. W. \& R. J. PODOLSKY. 1977. Influence of magnesium on chloride-induced calcium release in skinned muscle fibers. J. Gen. Physiol. 69: 17-35.

25. STEPHENSON, E. W. 1981. Calcium dependence of stimulated ${ }^{45}$ Ca efflux from skinned muscle fibers. J. Gen. Physiol. 77: 419-443.

26. Knudson, C. M., T. Imagawa, S. D. KaKL, M. G. Gaver, A. T. Leung, A. H. Sharp, S. D. JAY \& K. P. CAMPBELL. 1988. Evidence for physical association between junctional sarcoplasmic reticulum ryanodine receptor and junctional transverse tubular dihydropyridine receptor. Biophys. J. 53: 605a. 